\title{
ANALISIS PERBANDINGAN PENGATURAN HUKUM BUILD OPERATE TRANSFER (BOT) DI INDONESIA DENGAN NEGARA ASEAN
}

\author{
Muhammad Dzikirullah H. Noho ${ }^{1}$, Budi Santoso ${ }^{1}$, Paramita Prananingtyas ${ }^{1}$, \\ Trinah Asi Islami ${ }^{2}$ \\ ${ }^{1}$ Fakultas Hukum Universitas Diponegoro, Semarang \\ ${ }^{2}$ Fakultas Agama Islam Universitas Hasyim Asy'ari Tebuireng, Jombang \\ mdzikirullah94@gmail.com
}

\begin{abstract}
Abstrak
Tujuan penelitian ini untuk mengetahui dan menganalisis perbandingan pengaturan build operate transfer (BOT) diberbagai negara Asean sebagai acuan pembaharuan hukum BOT di Indonesia. Pembangunan infrastruktur baik sarana dan prasarana adalah kewajiban pemerintah. BOT sebagai alternatif pembiayaan harapannya dapat memenuhi kebutuhan itu. Namun pada tataran regulasi perlu juga diperbaiki agar dapat memberikan kepastian dan keadilan bagi semua pihak, seperti halnya regulasi BOT yang dibuat oleh Filipina yang kemudian membawa ketertarikan bagi swasta asing ataupun lokal untuk ikut terlibat membangun infrastruktur di negaranya. Metode penelitian yang digunakan adalah yuridis normatif dengan pendekatan perundang-undangan, konsep, dan perbandingan, bahan hukum yang dikumpulkan adalah bahan hukum sekunder baik itu putusan ataupun peraturan-peraturan terkait. Konsep umum BOT disebut project finance, dengan dua peserta utama, yaitu pemerintah tuan rumah dan sponsor swasta. BOT di Indonesia, Fililipina, Malaysia, dan Vietnam sangatlah beragam. Pengaturan ini dibuat menyesuaikan dengan kondisi negara masing-masing. Perbandingan BOT antara Indonesia dengan Filipina, Malaysia, dan Vietnam menjelaskan bahwa BOT di Indonesia masih sangat liberal dan tidak pro nasionalisasi, hal tersebut dapat dilihat pada tidak adanya aturan mengenai kepemilikan saham perusahan BOT yang dimiliki oleh orang Indonesia, bahkan jangka waktu konsesi, serta model penyelesaiannya.
\end{abstract}

Kata kunci : Build Operate Transfer; Perbandingan; Kerjasama

\section{COMPARISON ANALYSIS OF BUILD OPERATE TRANSFER (BOT) LEGAL REGULATIONS IN INDONESIA WITH ASEAN COUNTRIES}

\begin{abstract}
The purpose of this study is to determine and analyze the comparison of build operate transfer (BOT) regulations in various Asean countries as a reference to BOT law in Indonesia. Infrastructure development in both facilities and infrastructure is the government's obligation. BOT as an alternative to financing hopes to meet that need. However, at the level of regulation, it also needs to be improved to provide certainty and fairness for all parties, such as the Philippines' BOT regulations, which bring interest to the foreign or local private sector to build infrastructure in the country. The research method used is a normative juridical approach to legislation, concepts, and comparisons, the legal material collected is secondary legal material, both the decision or related regulations. The general concept of BOT is called Project Finance, with two main participants, namely the host government and private sponsors. BOTs in Indonesia, the Philippines, Malaysia, and Vietnam are very diverse. The conditions made this arrangement of each country. Comparison of BOT between Indonesia and the Philippines, Malaysia, and Vietnam explains that BOT in Indonesia is still very liberal and not pro nationalization; this can be seen in the absence of rules regarding the ownership of BOT company shares owned by Indonesians, even the duration of the concession, and the model the solution.
\end{abstract}

Keywords: Build Operate Transfer; Comparative; Cooperation 


\section{A. PENDAHULUAN}

Pembangunan nasional dalam bidang ekonomi terus meningkat, kebutuhan akan dana pun cukup besar. Keterbatasnya Anggaran Pendapatan dan Belanja Negara (APBN) oleh pemerintah pusat dan Anggaran Pendapatan dan Belanja Daerah (APBD) oleh pemerintah daerah untuk mendanai pembangunan infrastrtuktur memerlukan pengembangan relasi kemitraan yang saling timbal balik. Relasi tersebut berguna untuk keuntungan baik itu perusahan nasional maupun perusahan asing dengan tujuan untuk memperkokoh ekonomi nasional. Kerangka baru ini merupakan bentuk alternatif dalam pembiayaan infrastruktur pada setiap kegiatan proyek yang dilakukan pemerintah akan datang. ${ }^{1}$

Pembangunan infrastruktur baik sarana dan prasarana adalah kewajiban pemerintah. Hal ini merupakan salah satu bentuk pelayanan terhadap masyarakat di era globalisasi. Terbatasnya anggaran mengharuskan pemerintah perlu melibatkan pihak swasta dalam hal pembangunan dan pengoperasian sarana prasarana dalam hal terpenuhinya kebutuhan pelayanan masyarakat. Pembangunan baik sarana dan prasarana infrastruktur merupakan perwujudan dari pelayanan publik yang bertujuan untuk kesejahteraan masyarakat. Berbagai kerjasama dilakukan salah satunya melalui Publik Private Partnership (PPP). Konsep PPP ini adalah skema yang melibatkan kerjasama pemerintah dan swasta dalam bentuk perjanjian untuk memenuhi kebutuhan pelayanan terhadap masyarakat. $^{2}$

Istilah lain PPP merupakan Kerjasama Pemerintah Swasta selanjutnya disingkat dengan (KPS) adalah skema pembiayaan secara alternatif yang difungsikan oleh beberapa negara terutama negara maju dengan tujuan pengadaan pelayanan publik dalam bidang infrastruktur. $^{3}$ Masuknya pihak swasta/asing sebagai partner pemerintah untuk pembangunan infrastuktur berbasis pelayanan publik yang dapat mengakibatkan timbulnya berbagai bentuk perjanjian kerjasama. Bentuk-bentuk perjanjian kerjsama antara pihak swasta dengan pihak pemerintah, contohnya seperti build own operate (BOO), build operate transfer (BOT), kerjasama operasi/joint operation (KSO), build rent operate transfer (BROT), ruislag, gabungan usaha dengan cara patungan, dan sebagainya. ${ }^{4}$

Diantara model kerjasama swasta dengan pemerintah di atas yang sering digunakan oleh pihak pemerintah yakni skema BOT atau bangun guna serah (BGS). Kedudukan BOT dalam hirarki perundang-undangan saat ini diatur dalam Pasal 34 PP No. 27/2014 mengenai Pengelolan Barang Milik Negara/Daerah menjelaskan BOT/BGS merupakan

\footnotetext{
${ }^{1}$ Maeva Maishara, Hendro Saptono, dan R. Suharto, "Kajian Kerjasama Build, Operate And Transfer (BOT) Pada Pembangunan Pasar Modern Di Kabupaten Kudus," Diponegoro Law Review 5, no. 2 (2016): 1-10.

${ }^{2}$ Hidayatul Masitoh, "Public Private Partnership ( PPP ) Pengelolaan Aset Daerah: Studi Deskriptif tentang Kemitraan antara Perusahaan Daerah Pasar Surya ( PDPS ) Surabaya dengan PT Arwinto Intan Wijaya ( AIW ) dalam Pembangunan dan Pengembangan Darmo Trade Centre ( DTC ) Sur," Kebijkan dan Manajemen Publik 2, no. 1 (2014): $1-9$.

${ }^{3}$ Masitoh.

${ }^{4}$ Muhammad Dzikirullah H Noho, "Memaknai Hak Dan Kewajiban Dalam Kebijakankerjasama Swasta Dengan Pemerintah Daerah(Pemda) Melalui Perjanjian Build Operate Transfer (BOT) Bidang Pasar," The Journal of Society \& Media 3, no. 1 (2019): 51, https://doi.org/10.26740/jsm.v3n1.p51-67.
} 
suatu bentuk pemanfaatan barang milik negara/daerah. Selain PP BOT yang diatur oleh peraturan menteri, keputusan menteri, dan sebagainya.

Berdasarkan penjelasan di atas dapat dilihat bahwa kedudukan BOT dalam hirarki perundang-undangan sangatlah lemah, sementara keberadaan BOT ini sangat penting bagi pemerintah sebagai alternatif pembiayaan untuk membangun infrastruktur. Dampak dari lemahnya peraturan tersebut mengakibatkan kekacauan pada tataran implementasi seperti kasus-kasus BOT yang muncul akhir-akhir ini, salah satunya yaitu BOT Pasar Turi Surabaya.

Pada kasus tersebut menerangkan bahwa persoalan objek perjanjian yang semulanya merupakan hak pakai, namun pada kenyataannya oleh PT. Gala Bumi Sejahtera dalam memasarkan stand/kios Pasar Turi menjual stand/kios dengan hak milik atas satuan rumah susun. Apabila hal ini dilakukan maka kepemilikan bangunan Pasar Turi akan beralih kepada pedagang, sehingga pada masa akhir kerja sama bangun guna serah, Pemerintah Kota Surabaya tidak dapat menerima bangunan Pasar Turi secara utuh atau setidak-tidaknya akan menimbulkan kesulitan. Di sisi lain para pedagang juga telah membayar uang muka senilai $20 \%$ atau Rp. 5.000.000.- untuk mendapatkan stand dan pelunasaran $80 \%$ dibayarkan setelah bangunan jadi, karena adanya persoalan hukum maka pihak PT. Gala Bumi Perkasa memerintahkan kepada pedagang untuk melunasinya di awal.

Berbeda dengan beberapa negara ASEAN lainnya seperti Filipina. Di Filipina pengaturan BOT diletakan seperti halnya undang-undang di Indonesia yakni Republic Act No. 7718 and Philipphine and Revised Implementing Rules and Regulations Of R.A. No. 6957. Isi dalam aturan tersebut mengatur tentang mekanisme dan batas-batas menggunakan skema BOT, pengawasan serta evaluasi BOT. Menurut data yang dikeluarkan World Bank tentang Private Participation Infrastructure (PPI), bahwa keikutsertaan dari perusahaan swasta nasional Indonesia dibidang infrastruktur yakni sebesar $2 \%$. Jauh sekali apabila dibandingkan dengan proyek infrastruktur pihak swasta di Filipina yakni sebesar 44\%.5 Besar keinginan swasta untuk terlibat dalam pembangunan infrastruktur di Filipina salah satunya adalah kesiapan regulasi yaitu adanya salah satu peraturan hukum yang rigid dan pasti secara hukum.

Adapun penelitian terdahulu yaitu; pertama, penelitian oleh Disemadi (2019) menemukan bahwa kontrak BOT yang dilakukan dalam kerjasama pemerintah mempunyai dampak yang positif. Hadirnya BOT dapat dijadikan sebagai sarana dalam mewujudkan kesejahteraan bagi rakyat dan memenuhi hak asasi manusia. Apa yang diteliti tersebut memiliki kelebihan yaitu mengangkat HAM sebagai cara pandang dalam melihat pentingnya adanya BOT, namun kekurangnnya yaitu masih menempatkan BOT seperti kontrak pada umumnya. ${ }^{6}$

${ }^{5}$ Eka Budiyanti, "Strategi Peningkatan Peran Swasta dalam Pembangunan Infrastruktur," Pusat Penelitian Badan Keahlian DPR RI 10, no. 4 (2018).

${ }^{6}$ Hari Sutra Disemadi dan Kholis Roisah, "Kontrak Build Operate Transfer Sebagai Sarana Mewujudkan Kesejahteraan Rakyat," Jurnal Komunikasi Hukum 5, no. 2 (2019): 126. 
Kedua, penelitian oleh Lita (2018) menemukan bahwa BOT dapat dilakukan dalam pembangunan gedung dengan skema wakaf sesuai dengan Pasal 42 dan Pasal 43 UU wakaf. BOT dalam wakaf ini dapat terjadi apabila terdapat kesepakatan diantara mereka dan sesuai dengan prinsip-prinsip syariah. Kelebihan penelitian ini adalah menghadirkan BOT kedalam pembangunan bangunan dalam tanah wakaf. Kekurangannya adalah masih menempatkan BOT seperti kontrak pada umumnya. ${ }^{7}$

Ketiga, penelitian oleh Tamin (2017) menemukan bahwa supported build operate transfer efektif untuk diberikan kepada jalan tol yang membutuhkan biaya investasi yang relatif tinggi tetapi pendapatannya rendah. Sedangkan untuk jalan tol yang membutuhkan biaya investasi tinggi dan pendapatan tinggi, tidak disarankan untuk menerapkan Supported Build Operate Transfer. Kelebihan penelitian ini adalah melihat BOT sebagai investasi jalan tol tidaklah direkomendasikan disebabkan minimnya pendapatan di dalamnya. Kekurangannya tidak mengulas aspek kontrak dan regulasi penggunaan BOT. ${ }^{8}$

Bilamana dibandingkan dengan penelitian yang akan diteliti terdapat persamaan pada pengulasan BOT sebagai kerangka umum dalam penelitian ini, namun perbedaannya yaitu apa yang dibahas dalam penelitian lebih fokus pada peraturanperaturan BOT yang ada di Indonesia saat ini dan diperbandingkan dengan negara-negara ASEAN lainnya (Filipina, Malaysia, dan Vietnam). Dengan adanya ulasan diatas bertujuan untuk mengetahui dan menganalisis peraturan-peraturan di negara-negara tersebut dengan harapan dapat menjadi gambaran bagi Indonesia dalam membangun aturan hukum BOT yang akan datang.

\section{B. PERMASALAHAN}

Berdasarkan latar belakang di atas, memunculkan beberapa rumusan masalah yang akan diteliti yaitu (1) Bagaimana konsep build operate transfer pada umumnya? (2) Bagaimana pengaturan hukum build operate transfer di negara Asean? (3) Bagaimana perbandingan hukum build operate transfer antara Indonesia dengan Asean lainnya?

\section{METODE PENELITIAN}

Penelitian ini menggunakan metode dengan jenis penelitiaan yuridis normatif dan menggunakan pendekatan Per-UU-an, konsep, dan perbandingan. Sumber bahan hukum dalam penelitian ini menggunakan bahan hukum sekunder yaitu undang-undang dan putusan pengadilan. Metode pengumpulan bahan hukum dengan cara menginvetarisir dan mengklasifikasi PP BOT yang ada di Indonesia, Permendagri, peraturan BOT yang ada di Filipina, Malaysia dan Vietnam. Metode analisis bahan hukum dalam penelitian ini sesuai dengan rumusan permasalahan dan tujuan, maka dilakukan analisis normatifkualitatif, di mana berupaya mendeskripsikan undang-undang BOT yang ada baik di Indonesia, Filipina, Malaysia, dan Vietnam, memperbandingkan BOT keempat negara,

${ }^{7}$ Helza Nova Lita dan Eidy Sandra, "Perjanjian Build, Operate, And Transfer (BOT) Pada Kerjasama Pembangunan Commercial Building Diatas Tanah Wakaf berdasarkan Ketentuan Hukum Positif Indonesia," Al-Awqaf: Jurnal Wakaf Dan Ekonomi Islam 11, no. 1, (2018): 23-32.

${ }^{8}$ Rizal Z. Tamin, Iris Mahani, dan Puti F. Marzuki, "Supported Build Operate Transfer Effectiveness Analysis to Improve Financial Feasibility Of Toll Roads In Indonesia," Jurnal HPJI 3, no. 2 (2017): 129-138. 
kemudian menganalisa undang-undang yang ada agar dapat mengetahui kelebihan dan kekurangan dari empat negara dan menarikan kesimpulan atas hasil tersebut. ${ }^{9}$

\section{HASIL DAN PEMBAHASAN}

\section{Konsep BOT Pada Umumnya}

Konsepsi build operate transfer (BOT) pada umumnya telah ditetapkan proyek infrastrukturnya yang mencakup sebagai berikut: " To have any projects which really belonged to the public sector implemented by the private organization without the state, the province, the city or the commune providing any guarantee or accepting any liability. The project which was intended to be self-financing ". ${ }^{10}$

Secara umum BOT melibatkan enam pihak utama termasuk pemerintah tuan rumah, sponsor, pemberi pinjaman, investor, pengguna produk dan kontraktor. Namun, pemerintah tuan rumah dan sponsor adalah dua utama para pihak. Pemerintah tuan rumah mengacu tidak hanya pemerintah daerah tetapi juga pemerintah yang berwenang terlibat dalam proyek, sedangkan sponsor mengacu pada konsorsium, perusahaan proyek atau pengembang proyek. Mereka membuat perjanjian konsesi untuk menentukan ekuitas, tanggung jawab, berbagi, jaminan, dll. Secara khusus, pemerintah tuan rumah bertanggung jawab untuk mengawasi proyek, sementara perusahaan proyek bertanggung jawab untuk semua fase proyek melalui berbagai kontrak dengan pihak lain. ${ }^{11}$

BOT adalah metode kemitraan swasta-publik, yang berbeda dari privatisasi atau nasionalisasi seluruhnya: ${ }^{12}$

"In privatization, government owns an entity first and then transfer (sells) it to the private sectors. In contrast, in BOT projects private sector bears the cost of project first, then owns it for certain period before handling it over to the government at no cost."

Hal tersebut di atas merupakan daya tarik mendasar BOT. Ini tidak hanya menghilangkan pengeluaran dari neraca pemerintah tetapi juga menyediakan layanan kepada pengguna akhir (masyarakat umum) dalam tahap operasionalnya.

Model BOT adalah pendekatan perjanjian keuangan, dan melakukan sesuai dengan bentuk unik metode pembiayaan yang disebut project finance, dengan dua peserta utama, yaitu pemerintah tuan rumah dan sponsor swasta. Pemerintah tuan rumah adalah regulator publik yang bertanggung jawab untuk mengeluarkan izin, otorisasi dan lisensi atau konsesi proyek. Ini mungkin berdampak pada tarif, tol, biaya, dan aspek vital lainnya dari proyek. Sponsor swasta digambarkan oleh dewan investor atau entitas swasta yang bertugas merancang, membangun fasilitas, mendukung dan mengoperasikan fasilitas setelah jangka waktu yang disepakati disebut periode konsesi dan pengaturan untuk membiayai tahap-tahap siklus hidup proyek ini. Baik pembatasan anggaran dan

\footnotetext{
${ }^{9}$ Teguh Tresna Puja Asmara dan Tarsisius Murwadji, Telaah Yuridis Penerapan Konsep Quadruplehelix Pada Pelaksanaan CSR Bagi UMKM", Jurnal Legislasi Indonesia 17, no. 1, (2020): 42.

${ }^{10}$ Budi Santoso. Aspek Hukum Pembiayaan Proyek Infrastruktur dengan Model BOT (Build Operate Transfer), (Yogyakarta: Genta Press, 2008)

${ }^{11}$ Jiaju Yang, Tahir M Nisar, Dan Guru Prakash Prabhakar, "Critical Success Factors For Build-OperateTransfer (BOT) projects in China," The Irish Journal of Management 36, no. 3 (2017): 147-61, https://doi.org/10.1515/ijm-2017-0016.

${ }^{12}$ S Mubin dan A Ghaffar, "BOT Contracts: Applicability in Pakistan for Infrastructure Development ," Pakistani Journal of Engineering and Applied Sciences 3, no. January 2008 (2008): 1-14.
} 
kompleksitas sektor publik untuk memenuhi persyaratan hari ini serta mendorong model BOT untuk diadopsi di negara-negara berkembang. ${ }^{13}$

\section{Pengaturan Hukum BOT di Berbagai Negara ASEAN}

\section{a. Pengaturan Hukum BOT di Filipina}

Lahirnya Undang-Undang Build-Operate-and Transfer (BOT) (Undang-Undang Republik 6957, sebagaimana diubah oleh Undang-Undang Republik 7718 membuka jalan bagi keterlibatan sektor swasta dalam keuangan, konstruksi dan pengoperasian fasilitas dan layanan infrastruktur publik yang vital. Proyek BOT yang lengkap termasuk jalan tol, sistem angkutan kereta massal (MRT), dan pembangkit listrik yang mencegah krisis energi yang akan datang. ${ }^{14}$

Untuk mempercepat pembangunan infrastruktur yang sangat dibutuhkan untuk pembangunan, pemerintah negara-negara berkembang telah menggunakan skema buildoperate-transfer (BOT). Pemerintah Filipina, yang ingin memanfaatkan skema semacam itu,melalui Undang-Undang Republik No. 6957 (Undang-Undang Build-OperateTransfer dengan amandemen kemudian oleh R.A No. 7718) yang disetujui pada Juli 1990 untuk mencakup jalan raya, jembatan, simpang susun, terowongan, fasilitas angkutan massal, jalur air darat yang dapat dilayari, kereta api, bandara, pembangkit listrik, distribusi daya, telekomunikasi, irigasi, pasokan air, saluran air kotor, drainase, infrastruktur kesehatan, tanah reklamasi, pengerukan, kawasan industri, pasar, rumah potong hewan, pelabuhan ikan, insinerator, TPA dan fasilitas terkait. ${ }^{15}$

Menurut R.A. No. 6957 — dengan amandemen masing-masing oleh R.A. No. 7718 — bulid operate transfer setidaknya memuat yakni pengalihan proyek terhadap fasilitasfasilitas pada Pemerintah baik pusat maupun daerah dalam jangka waktu yang telah ditetapkan maksimal 50 tahun dengan syarat bahwa dalam hal suatu sarana prasarana atau fasilitas pembangunan yang operasinya memerlukan kemanfaatan waralaba maka harus berasal dari orang Filipina atau perusahaan yang terdaftar pada sekuritas maka saham yang dimiliki setidaknya $60 \%$ adalah orang Filipina.

Masa konsesi dimulai dari penandatanganan konsesi perjanjian antara pemerintah dan sektor swasta menunjukkan rentang waktu di mana sektor swasta bertanggung jawab atas fase konstruksi dan fase operasi proyek BOT. Di Filipina, panjang konsesi periode biasanya ditentukan oleh pelaksana infrastruktur / kantor pusat. ${ }^{16}$

\section{b. Pengaturan Hukum BOT di Malaysia}

Malaysia telah membuat skema BOT sebagai komponen utama strategi privatisasi. Telah dinyatakan bahwa skema BOT akan menjadi landasan dari rencana untuk mencapai

${ }^{13}$ Hassan Sharaffudin dan Abdullah AL-Mutairi, "Success Factors for the Implementation of Build Operate Transfer (BOT) Projects in Kuwait," International Journal of Business and Management 10, no. 9 (2015): 68-78, https://doi.org/10.5539/ijbm.v10n9p68.

${ }^{14}$ Gilberto M. Llanto, A Review of Build-Operate-Transfer for Infrastructure Development: Some Lessons for Policy Reform (Makati: Philippine Institute for Development Studies, 2008).

${ }^{15}$ Maria Victoria Y. Sibal, The Effectiveness And Efficiency Of The Build-Operate-Transfer (BOT) Scheme In The Philippine Context Of Economic Development (A Case Study) (Manila: De La Salle-College of Saint Benilde, 2007).

${ }^{16}$ Shinya Hanaoka dan Hazel Perez Palapus, "Reasonable Concession Period For Build-Operate-Transfer Road Projects In The Philippines," International Journal of Project Management 30, no. 8 (2012): 938-49, https://doi.org/10.1016/j.ijproman.2012.02.001. 
industri baru negara sebelum pergantian abad. Selain perannya sebagai alat privatisasi, BOT telah diteruskan sebagai kendaraan untuk mencapai ambisius tujuan pembangunan infrastruktur tujuan. Seperti yang direkomendasikan oleh Rencana Induk Privatisasi, 79 (tujuh puluh sembilan) proyek baru yang dimiliki telah disetujui untuk diprivatisasi oleh gugus privatisasi menggunakan skema BOT atau BOT sebagai metode utama privatisasi. Karena sifat proyek makro, keuangan, teknis, dan manajerial sumber daya yang dibutuhkan sangat besar dan pasti akan membutuhkan partisipasi asing secara luas. ${ }^{17}$

Pemerintah Malaysia telah mengadopsi pendekatan khusus legislasi dalam mengelola proyek BOT. Misalnya di sektor transportasi jalan, jalan federal (privat management) Act 1984 diberlakukan untuk memungkinkan Pemerintah memberikan hibah kepada pengembang swasta hak untuk mengumpulkan tol di jalan umum. Undangundang ini memungkinkan pengembang swasta untuk membangun, mengoperasikan dan memelihara sistem jalan baru dan setelah itu memulihkan biaya untuk melakukan pengumpulan tol. Pengaturan keamanan disesuaikan dengan sifat BOT dari suatu proyek biasanya diatur melalui perjanjian proyek, perjanjian pembelian, dan perjanjian kredit. Perjanjian tersebut dapat mencakup pendapatan luar negeri dan akun retensi, pelaksanaan kinerja dari pemerintah kewajiban lembaga publik berdasarkan perjanjian proyek, penugasan berbagai kontrak kepada pemberi pinjaman, hak pemberi pinjaman untuk menyehatkan kegagalan apapun oleh perusahaan proyek dalam waktu yang wajar dan hak mereka untuk mengambil alih BOT memproyeksikan dalam kasus yang gagal. Pemilik ekuitas perusahaan proyek juga menjaminkan semua saham mereka sebagai jaminan untuk pinjaman. ${ }^{18}$

Beberapa syarat dan ketentuan kontrak konsesi perlu penelitian lebih lanjut dan negosiasi ulang dalam melindungi kepentingan para pihak. Di antara aspek-aspek penting yang perlu dipertimbangkan adalah sebagai berikut: ${ }^{19}$ 1) hak eksklusif, harus dipertimbangkan kembali untuk menghindari monopoli layanan dan menciptakan persaingan sehat antar perusahaan yang akan menguntungkan pemerintah dan publik;, 2) jaminan pemerintah kepada perusahaan dan peminjam, klausul perlu dipertimbangkan kembali untuk menghindari beban keuangan yang tidak perlu pembayaran pemerintah pada tingkat hutang dan kompensasi kepada pemegang konsesi jika estimasi pendapatan, laba, dan laju volume untuk tahun tertentu yang tidak tercapai; 3) hak untuk memutus kontrak / konsesi, formulir klausul tentang hak untuk mengakhiri kontrak atau konsesi oleh pemerintah jika perusahaan gagal memenuhi persyaratan dan ketentuan kontrak sesuai dengan standar proyek yang disepakati; kondisi pada pemegang saham dengan menyatakan bahwa ada perubahan pada struktur.

${ }^{17}$ Matthew L. Hensley dan Edward P. White, "The Privatization Experience In Malaysia. Integrating BuildOperate-Own And Build-Operate-Transfer Techniques Within The National Privatization Strategy," Columbia Journal of World Business 28, no. 1 (1993): 70-82, https://doi.org/10.1016/0022-5428(93)90055-T.

${ }^{18}$ Ruzian Markom dan Engku Rabiah Adawiah Engku Ali, "A Legal Analysis Of Successful And Problematic Build Operate And Transfer (BOT) Projects In Malaysia," International Journal of Business and Society 13, no. 2 (2012): 133-50.

${ }^{19}$ Markom dan Ali, 148. 
Konsesi berlaku untuk jangka waktu terbatas, biasanya 15- 25 tahun tergantung pada sifat proyek. Skema BOT, yang biasanya sangat mempengaruhi, pembiayaan utang dinaikkan oleh perusahaan proyek atau konsorsium dari sumber komersial dan biasanya didukung oleh jaminan kredit ekspor lembaga pemberi pinjaman baik bilateral dan multilateral lainnya. ${ }^{20}$

\section{c. Pengaturan Hukum BOT di Vietnam}

Vietnam sebagai salah satu negara anggota ASEAN yang menerima modal besar dari investasi oleh negara-negara Asia lainnya. Perubahan terbaru menuju modernisasi infrastruktur Vietnam yang belum berkembang tetap menjadi penghalang substansial untuk pertumbuhan ekonomi yang berkelanjutan. Dengan demikian, dalam upaya untuk "mendorong investasi dalam konstruksi dan pengembangan infrastruktur di Vietnam, "pemerintah mengeluarkan keputusan pada kontrak build-operate-transfer (Keputusan BOT) dan Peraturan tentang investasi dalam bentuk kontrak build-operate-transfer (Peraturan BOT) pada 23 November 1993. The State Committee for Cooperation and Investment (SCCI) mengeluarkan Surat Edaran tentang BOT pada tanggal 28 Februari 1994 untuk semakin memperjelas dan memperluas peraturan awal. ${ }^{21}$

Peraturan BOT Vietnam diundangkan pada tanggal 23 November 1993, ditetapkan kerangka kerja untuk membentuk proyek BOT. Investor mendirikan perusahaan BOT dan membangun dan mengoperasikan proyek untuk jangka waktu tertentu, diikuti oleh pengalihan proyek tanpa kompensasi ke pemerintah Vietnam. Beberapa keutamaan hukum BOT adalah sebagai berikut: ${ }^{22}$

1) Pemerintah Vietnam akan melindungi hak kepemilikan modal yang diinvestasikan.

2) Tol dan sumber pendapatan lainnya harus ditetapkan dalam kontrak BOT, dengan perubahan apa pun di masa depan yang melampaui batas yang diizinkan hanya melalui proposal ke SCCI.

3) Pemilihan BOT dapat dilakukan melalui penawaran, pemilihan, atau perundingan langsung.

4) Perusahaan BOT dapat berada selama 20 tahun atau" [diperlukan], kemudian diperpanjang dalam jangka waktu yang lebih lama.

5) Setelah menyelesaikan periode waktu yang ditentukan, proyek BOT harus ditransfer seluruhnya ke pemerintah Vietnam tanpa kompensasi.

6) Perselisihan antara perusahaan BOT dan kontraktor tambahan ditangani melalui negosiasi dan konsiliasi. Perselisihan yang belum terselesaikan mungkin dirujuk ke badan arbitrase yang disepakati oleh para pihak.

7) Perselisihan antara perusahaan BOT dan pemerintah Vietnam diselesaikan melalui negosiasi dan konsiliasi. Sengketa yang tersisa dirujuk ke arbitrator ad-hoc.

\footnotetext{
${ }^{20}$ Hensley dan White, "The Privatization Experience In Malaysia. Integrating Build-Operate-Own And BuildOperate-Transfer Techniques Within The National Privatization Strategy," 79.

${ }^{21}$ Laura A Malinasky, "Rebuilding with Broken Tools : Build-Operate- Transfer Law in Vietnam Rebuilding With Broken Tools : Build- By,” Berkeley Journal of International Law 14, no. 2 (1996).

${ }^{22}$ Malinasky.
} 
Adapun maksud perubahan undang-undang BOT di antaranya lima dari perubahan paling berharga meliputi: melindungi dari pengambilalihan atau nasionalisasi; mengadopsi mekanisme stabilisasi; mengklarifikasi peraturan tarif tol; memperluas kerangka waktu untuk proyek BOT; dan meningkatkan akses informasi. Mengatasi masalah ini akan meningkatkan struktur hukum untuk investasi BOT di Vietnam dan akan mengurangi sebagian risiko investasi.

\section{Perbandingan Hukum BOT Antara Indonesia Dengan Negara ASEAN Lainnya a. Pengaturan Hukum BOT di Indonesia Saat ini}

Di Indonesia, BOT adalah kontrak non-pengadaan dalam kerangka kerja pelayanan publik yang dilakukan oleh pemerintah dengan pihak swasta. Di Indonesia, BOT diatur dalam Pasal 1 ayat 12 PP. 38/2008 dan Pasal 1 ayat 14 PP. 27/2014 yang pada intinya bahwa BGS secara definitif merupakan pemanfaatan property negara/lokal dalam bentuk benda tidak bergerak oleh pihak lain yang berdiri diatasnya sebuah bangunan atau fasilitas dan dimanfaatkan dalam jangka waktu tertentu yang telah ditentukan dan atau diperjanjikan yang selanjutnya tanah atau fasilitas tersebut dikembalikan manakala jangka waktu tersebut telah berakhir.

Mengacu pada PP tersebut di atas maka salah satu grafik pemanfaatan barang milik negara/daerah adalah build operate transfer (BOT). BOT dapat dilaksanakan apabila pengguna mengingkan fasilitas dan bangunan. Penyelenggaraan dapat dilakukan oleh pemerintah baik pusat maupun daerah untuk kebutuhan pelayanan umum. Hal tersebut merupakan tugas dan fungsinya akibat tidak adanya pendanaan dalam platform APBN/APBD dalam menyediakan fasilitas dan bangunan untuk pelayanan umum.

Telah ditetapkan jangka waktu BGS yakni maksimal 30 tahun pada saat ditandatanganinya perjanjian kerjasama. Jangka waktu pengoperasian hasil BGS tersebut dapat secara langsung diperuntukkan bagi penyelenggaraan tugas dan fungsi pemerintah pusat/daerah minimal 10\%. BGS sekurang-kurangnya dapat dilakukan apabila perjanian kerjasama memuat: ${ }^{23}$

a. Adanya para pihak;

b. Adanya objek;

c. Jangka waktu yang ditentukan; dan

d. Hak dan kewajiban para pihak dalam perjanjian.

Ketentuan Pasal 1 ayat 36 Permendagri No. 19/2016 bahwa BOT adalah pemanfaatan properti regional dalam bentuk tanah untuk mendirikan bangunan dan/atau fasilitas sesuai jangka waktu tertentu yang telah disepakati, dan dikembalikan lagi penggunaan tanah beserta bangunan atau fasilitas-fasilitas setelah berakhirnya jangka waktu. ${ }^{24}$ Secara umum, kerja sama dalam bentuk apa pun termasuk BOT dimulai oleh perjanjian yang harus dicapai oleh para pihak. Perjanjian BOT menyediakan mekanisme

${ }^{23}$ Muhammad Dzikirullah H. Noho, "Politik Hukum Pengaturan Build Operate Transfer (Bot) Di Indonesia: Di Masa Lalu, Saat Ini, Dan Akan Datang," Jurnal Hukum Media Bhakti 3, no. 1 (2019): 88-99, https://doi.org/10.32501/jhmb.v3i1.51.

${ }^{24}$ Eventia, "Legal Principles in Function and Performance of BOT Contract," 527. 
kerja sama, berbagai ketentuan atau pedoman, pengaturan hak dan pembagian kewajiban antara para pihak secara adil dan seimbang (proporsional). ${ }^{25}$

Pemanfaatan lahan dengan model BOT menggunakan lahan yang cukup besar (umumnya lebih besar dari 1 \{satu\} ha). Kerjasama BOT dalam pemanfaatan dan pengelolaan tanah adalah bentuk dari pembiayaan proyek pengembangan infrastruktur. Bentuk pemanfaatan dan pengelolaan tersebut seperti pengembangan mal, hotel, wisata tempat, gedung perkantoran, jalan tol, pelabuhan, bandara, dll, di mana semuanya membutuhkan lahan yang luas. Dengan adanya BOT, pengusaha yang memiliki niat untuk berinvestasi tidak perlu membeli atau memiliki tanah, tetapi cukup untuk mengembangkan dan mengelola dan mengoperasikan gedung dan fasilitas di tanah pihak lain. $^{26}$

\section{b. Analisis Perbandingan BOT Indonesia dengan Negara ASEAN Lainnya}

Build operate transfer (BOT) dari berbagai penjelasan secara eksplisit sebagai model pembiayaan infrastruktur dengan membebankan keuangan pembangunan kepada investor melalui konsesi yang diberikan oleh pemerintah. Dasar berjalannya pembiayaan BOT ini adalah peraturan-peraturan yang tegas dan adil dengan tujuan memberikan perlindungan hukum dari keduanya. Dalam teori hukum pembiayan bangunan utamanya adalah sebuah sistem yang memberikan kepastian. Kepastian berupa pilihan dalam memilih keluar dari sistem hukum dan membentuk sistem mereka sendiri, namun sistem ini juga harus terikat aturan umum. Kredibilitas dan nilai kontrak pembiayaan yang sepadan bergantung pada dukungan aturan yang pasti. Hal ini memberikan pemahaman bahwa pendelegasian implisit pembuatan peraturan kepada aktor-aktor non-negara yang berbeda, pemahaman bahwa dalam semua hal juga membutuhkan perlindungan hukum secara penuh, agar tidak membuat para investor ini tidak memiliki atau kurang aturan atau di luar hukum. ${ }^{27}$

Oleh karenanya dalam pembiayaan BOT juga diperlukan kepastian hukum terhadap para investor atau pihak terkait. Negara-negara ASEAN diantaranya Indonesia, Filipina, Malaysia, dan Vietnam juga mengarah pada kepastian dan keadilan hukum tersebut. Maka untuk mengetahui perlindungan hukum yang diberikan negara-negara ASEAN di atas terhadap pembiayaan BOT, akan dilakukan penelusuran melalui perbandingan hukum dengan meninjau perbedaan dan persamaan:

${ }^{25}$ Irawan Soerodjo, "The Practice of Cooperation with Build, Operate \& Transfer ( BOT ) Model in Indonesia," Journal of Law, Policy and Globalization 49 (2016): 56-61.

${ }^{26}$ Soerodjo, 60.

${ }^{27}$ Katharina Pistor, “A Legal Theory Of Finance,” Journal of Comparative Economics 41, no. 2 (2013): 315 30, https://doi.org/10.1016/j.jce.2013.03.003. 
Tabel 1.

Perbedaan Pengaturan Build Operate Transfer Antara Indonesia, Filipina, Malaysia dan Vietnam

\begin{tabular}{|c|c|c|c|c|}
\hline Perbedaan & Indonesia & Filipina & Malaysia & Vietnam \\
\hline Pengertian & $\begin{array}{l}\text { Bentuk } \\
\text { perjanjian } \\
\text { kerja sama } \\
\text { yang dibuat } \\
\text { antara } \\
\text { pemegang hak } \\
\text { atas tanah } \\
\text { dengan } \\
\text { investor }\end{array}$ & $\begin{array}{l}\text { Pengaturan } \\
\text { kontrak di mana } \\
\text { pemrakarsa } \\
\text { proyek } \\
\text { melakukan } \\
\text { pembangunan, } \\
\text { termasuk } \\
\text { pembiayaan, } \\
\text { pemrakarsa } \\
\text { dimiliki hingga } \\
\text { setidaknya enam } \\
\text { puluh persen } \\
\text { (60\%) oleh orang } \\
\text { Filipina. }\end{array}$ & $\begin{array}{l}\text { Kontrak } \\
\text { melibatkan } \\
\text { investasi } \\
\text { swasta modal } \\
\text { oleh } \\
\text { konsorsium } \\
\text { perusahaan } \\
\text { untuk } \\
\text { merancang, } \\
\text { membiayai, } \\
\text { membangun, } \\
\text { mengoperasi } \\
\text { kan. }\end{array}$ & $\begin{array}{l}\text { Investor } \\
\text { mendirikan } \\
\text { perusahaan BOT } \\
\text { dan membangun } \\
\text { dan } \\
\text { mengoperasikan } \\
\text { proyek untuk } \\
\text { jangka waktu } \\
\text { tertentu, diikuti } \\
\text { oleh pengalihan } \\
\text { proyek tanpa } \\
\text { kompensasi ke } \\
\text { pemerintah } \\
\text { Vietnam. }\end{array}$ \\
\hline $\begin{array}{l}\text { Jangka } \\
\text { Waktu } \\
\text { Konsesi }\end{array}$ & $\begin{array}{l}30 \text { Tahun } \\
\text { dapat } \\
\text { diperpanjang }\end{array}$ & $\begin{array}{l}\text { Tidak lebih } 50 \\
\text { tahun }\end{array}$ & $\begin{array}{l}\text { 15-25 Tahun } \\
\text { tergantung } \\
\text { proyek }\end{array}$ & $\begin{array}{l}20 \text { Tahun dapat } \\
\text { diperpanjang }\end{array}$ \\
\hline Bidang BOT & $\begin{array}{l}\text { Pengembangan } \\
\text { mal, hotel, } \\
\text { wisata tempat, } \\
\text { gedung } \\
\text { perkantoran, } \\
\text { jalan tol, } \\
\text { pelabuhan, } \\
\text { bandara }\end{array}$ & $\begin{array}{l}\text { Jalan raya, } \\
\text { jembatan, } \\
\text { simpang susun, } \\
\text { terowongan, } \\
\text { fasilitas angkutan } \\
\text { massal, jalur air } \\
\text { darat yang dapat } \\
\text { dilayari, dll }\end{array}$ & - & $\begin{array}{l}\text { Pemilihan BOT } \\
\text { dapat dilakukan } \\
\text { melalui } \\
\text { penawaran, } \\
\text { pemilihan, atau } \\
\text { langsung } \\
\text { perundingan }\end{array}$ \\
\hline $\begin{array}{l}\text { Model } \\
\text { Penyelesaian } \\
\text { BOT }\end{array}$ & Sesuai kontrak & - & $\begin{array}{l}\text { Perselisihan } \\
\text { dilakukan } \\
\text { melalui } \\
\text { negosiasi. }\end{array}$ & $\begin{array}{l}\text { Perusahan BOT } \\
\text { dan kontraktor } \\
\text { tambahan melalui } \\
\text { negosiasi dan } \\
\text { konsiliasi dan } \\
\text { badan arbitrase }\end{array}$ \\
\hline
\end{tabular}


Tabel 2.

Persamaan Build Operate Transfer Antara Indonesia, Filipina, Malaysia, dan Vietnam

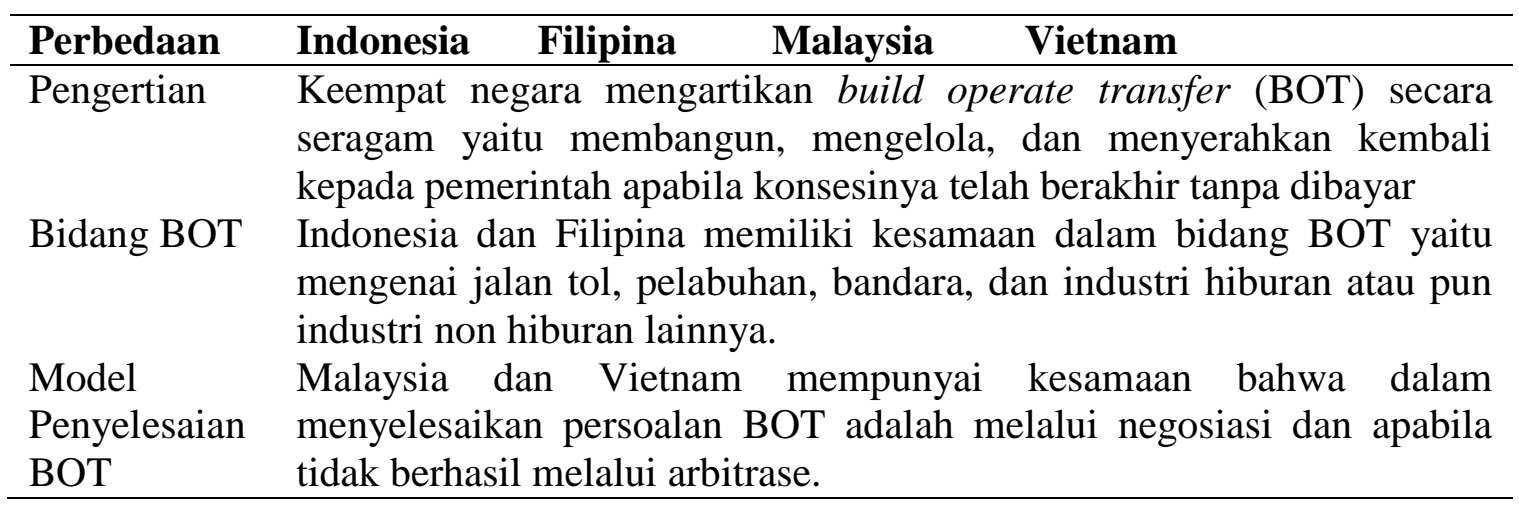

Berdasarkan tabel 1. perbedaan pengaturan build operate transfer antara Indonesia, Filipina, Malaysia, dan Vietnam dan tabel 2. persamaan build operate transfer antara Indonesia, Filipina, Malaysia, dan Vietnam di atas maka dapat dilihat bahwa terdapat banyak perbedaan dalam pengaturan BOT dari negara ASEAN tersebut. Perbedaan hukum BOT yang tergambarkan di atas memberikan pemahaman bahwa dengan adanya perbedaan di atas dapat dijadikan pertimbangan untuk merubah BOT pada tiap-tiap negara ada kedepannya.

Pertama, perbandingan BOT Indonesia dengan Filipina di atas maka dapat dilihat bahwa skema pembiayaan di Indonesia masih sangat liberal. Kepentingan nasional tidak begitu diutamakan dikarenakan tidak adanya ketegasan terhadap investor utamanya kepemilikan saham. Bidang-bidang yang boleh dilaksanakan dengan skema BOT oleh Filipina pun sangat banyak dan terlihat bahwa bidang-bidang tersebut hampir rata-rata bidang pelayanan publik kepada masyarakat. Sedangkan Indonesia sangatlah minim mengkategorisasikan bidang BOT nya. Namun yang menjadi kekurangannya adalah keduanya tidak memiliki skema penyelesaian dengan model BOT.

Kedua, Perbandingan BOT Indonesia dengan Malaysia secara umum masih terlihat sama. Yang menjadi menarik dari BOT Malaysia adalah jangka waktu yang diberikan sangatlah sedikit, di mana tentukan sesuai dengan proyek. Hal ini menunjukan bahwa Malaysia berkenginginan agar seluruh infrastruktur yang dikerjasamakan dalam bentuk BOT dapat segera dikelola oleh pemerintahannya. Bahkan dalam hal penyelesaian Malaysia lebih tepat karena mengutamakan jalur negosiasi, di mana jalur ini mengurangi konflik kepentingan di dalamnya. Indonesia perlu mengadopsi hal-hal baik yang terdapat dalam pengaturan BOT Malaysia.

Ketiga, Perbandingan BOT Indonesia dengan Vietnam secara pengertian secara umum sama, namun yang menjadi menarik adalah adanya seluruh proyek berlaku konsesinya adalah 20 Tahun. Jangka waktu tersebut sangatlah tepat karena dengan begitu 
pemerintah lebih cepat memiliki asetnya. Akan tetapi yang menjadi kekurangan dari pengaturan BOT Vietnam adalah tidak ditentukan bidang BOT sebagaiamana diatur oleh Indonesia, sehingga Vietnam perlu mempertimbangkan bidang BOT dalam pengaturannya kedepannya. Hal lain juga dengan Indonesia yang perlu mempertimbangkan model penyelesaian yang diadopsi dalam pengaturan BOT di Vietnam.

\section{E. PENUTUP}

Perbandingan pengaturan hukum build operate transfer (BOT) di Indonesia dengan negara-negara Asean ditemukan perbedaan yang signifikan dalam pengaturannya. Konsep build operate transfer yaitu proyek yang melibatkan enam pihak utama termasuk pemerintah tuan rumah, sponsor, pemberi pinjaman, investor, pengguna produk dan kontraktor. Pemerintah sebagai tuan rumah dan sponsor adalah dua utama para pihak. Pemerintah tuan rumah mengacu tidak hanya pemerintah daerah tetapi juga pemerintah yang berwenang terlibat dalam proyek, sedangkan sponsor mengacu pada konsorsium, perusahaan proyek atau pengembang proyek. Mereka membuat perjanjian konsesi untuk menentukan ekuitas, tanggung jawab, berbagi, jaminan, dan lain-lain. Pengaturan hukum build operate transfer (BOT) di negara ASEAN dilaksanakan sesuai dengan dengan kondisi negara masing-masing, misalnya dapat dilihat pada pengertian BOT dan bidangbidang BOT. Pada perbandingan BOT antara Indonesia dengan Filipina, Malaysia, dan Vietnam menjelaskan bahwa BOT di Indonesia masih sangat liberal dan tidak pro nasionalisasi, hal tersebut dapat dilihat pada tidak adanya aturan mengenai kepemilikan saham perusahan BOT yang dimiliki oleh orang Indonesia. Lebih lanjut jangka waktu konsesi yang ditentukan oleh Indonesia sangatlah elastis, begitu juga dengan model penyelesaiannya yang hampir tiap kasusnya berakhir di pengadilan. Harapan yang akan datang pemerintah Indonesia dapat membuat suatu peraturan yang akodomatif atas kepentingan-kepentingan baik swasta maupun publik.

\section{DAFTAR PUSTAKA}

Asmara, Teguh Tresna Puja, dan Tarsisius Murwadji, "Telaah Yuridis Penerapan Konsep Quadruplehelix Pada Pelaksanaan CSR Bagi UMKM", Jurnal Legislasi Indonesia 17, no. 1, (2020): 42.

Budi Santoso. Aspek Hukum Pembiayaan Proyek Infrastruktur dengan Model BOT (Build Operate Transfer). Yogyakarta: Genta Press, 2008.

Budiyanti, Eka. "Strategi Peningkatan Peran Swasta dalam Pembangunan Infrastruktur." Pusat Penelitian Badan Keahlian DPR RI 10, no. 4 (2018).

Disemadi, Hari Sutra, dan Kholis Roisah, "Kontrak Build Operate Transfer Sebagai Sarana Mewujudkan Kesejahteraan Rakyat," Jurnal Komunikasi Hukum 5, no. 2 (2019): 126.

Direktorat Putusan Mahkamah Agung Republik Indonesia No.296/Pdt.G/2016/PN. 
Eventia, Reifon Cristabella. "Legal Principles in Function and Performance of BOT Contract." Yuridika 32, no. 3 (2017): 521. https://doi.org/10.20473/ydk.v32i3.4798. Hanaoka, Shinya, dan Hazel Perez Palapus. "Reasonable Concession Period For BuildOperate-Transfer Road Projects In The Philippines.” International Journal of $\begin{array}{lllll}\text { Project Management } & 30, & \text { no. } & 8 & \text { (2012): }\end{array}$ https://doi.org/10.1016/j.ijproman.2012.02.001.

Hensley, Matthew L., dan Edward P. White. "The Privatization Experience In Malaysia. Integrating Build-Operate-Own And Build-Operate-Transfer Techniques Within The National Privatization Strategy." Columbia Journal of World Business 28, no. 1 (1993): 70-82. https://doi.org/10.1016/0022-5428(93)90055-T.

Lianto, Gilberto M. A Review of Build-Operate-Transfer for Infrastructure Development: Some Lessons for Policy Reform. Makati: Philippine Institute for Development Studies, 2008.

Lita, Helza Nova, dan Eidy Sandra, "Perjanjian Build, Operate, And Transfer (BOT) Pada Kerjasama Pembangunan Commercial Building Diatas Tanah Wakaf berdasarkan Ketentuan Hukum Positif Indonesia," Al-Awqaf: Jurnal Wakaf Dan Ekonomi Islam 11, no. 1, (2018): 23-32.

Maishara, Maeva, Hendro Saptono, dan R. Suharto. "Kajian Kerjasama Build, Operate And Transfer (BOT) Pada Pembangunan Pasar Modern Di Kabupaten Kudus." Diponegoro Law Review 5, no. 2 (2016): 1-10.

Malinasky, Laura A. "Rebuilding with Broken Tools : Build-Operate- Transfer Law in Vietnam Rebuilding With Broken Tools: Build- By." Berkeley Journal of International Law 14, no. 2 (1996).

Markom, Ruzian, dan Engku Rabiah Adawiah Engku Ali. “A Legal Analysis Of Successful And Problematic Build Operate And Transfer (BOT) projects in Malaysia." International Journal of Business and Society 13, no. 2 (2012): 133-50. Masitoh, Hidayatul. "Public Private Partnership ( PPP ) Pengelolaan Aset Daerah: Studi Deskriptif tentang Kemitraan antara Perusahaan Daerah Pasar Surya ( PDPS ) Surabaya dengan PT Arwinto Intan Wijaya ( AIW ) dalam Pembangunan dan Pengembangan Darmo Trade Centre ( DTC ) Sur." Kebijkan dan Manajemen Publik 2, no. 1 (2014): 1-9.

Mubin, S, dan A Ghaffar. "Bot Contracts: Applicability in Pakistan for Infrastructure Development ." Pakistani Journal of Engineering and Applied Sciences 3, no. January 2008 (2008): 1-14.

Noho, Muhammad Dzikirullah H. "Memaknai Hak Dan Kewajiban Dalam Kebijakan kerjasama Swasta Dengan Pemerintah Daerah (Pemda) Melalui Perjanjian Build Operate Transfer (BOT) Bidang Pasar.” The Journal of Society \& Media 3, no. 1 (2019): 51. https://doi.org/10.26740/jsm.v3n1.p51-67. 
Noho, Muhammad Dzikirullah H. "Politik Hukum Pengaturan Build Operate Transfer (Bot) Di Indonesia: Di Masa Lalu, Saat Ini, Dan Akan Datang." Jurnal Hukum Media Bhakti 3, no. 1 (2019): 88-99. https://doi.org/10.32501/jhmb.v3i1.51.

Peraturan Pemerintah No. 27 Tahun 2014 tentang Pengelolan Barang Milik Negara/Daerah

Peraturan Menteri Dalam Negeir No. 19 Tahun 2016 Tentang Pedoman Pengelolaan Barang Milik Daerah

Pistor, Katharina. "A Legal Theory Of Finance.” Journal of Comparative Economics 41, no. 2 (2013): 315-30. https://doi.org/10.1016/j.jce.2013.03.003.

Republic Act No. 7718 and Philipphine and Revised Implementing Rules and Regulations Of R.A. No. 6957

Sharaffudin, Hassan, dan Abdullah AL-Mutairi. "Success Factors for the Implementation of Build Operate Transfer (BOT) Projects in Kuwait." International Journal of Business and Management 10, no. 9 (2015): 68-78. https://doi.org/10.5539/ijbm.v10n9p68.

Sibal, Maria Victoria Y. The Effectiveness And Efficiency Of The Build-Operate-Transfer (BOT) Scheme In The Philippine Context Of Economic Development (A Case Study). Manila: De La Salle-College of Saint Benilde, 2007.

Soerodjo, Irawan. "The Practice of Cooperation with Build, Operate \& Transfer ( BOT ) Model in Indonesia." Journal of Law, Policy and Globalization 49 (2016): 56-61.

Tamin, Rizal Z., Iris Mahani, dan Puti, F. Marzuki, "Supported Build Operate Transfer Effectiveness Analysis to Improve Financial Feasibility Of Toll Roads In Indonesia," Jurnal HPJI 3, no. 2 (2017): 129-138.

Yang, Jiaju, Tahir M Nisar, dan Guru Prakash Prabhakar. "Critical Success Factors For Build-Operate-Transfer (BOT) projects in China." The Irish Journal of Management 36, no. 3 (2017): 147-61. https://doi.org/10.1515/ijm-2017-0016. 